J. Environ. Sci.

Institute of Environmental Studies and Research - Ain Shams University

\title{
LIVER STIFFNESS MEASURMENT BY FIBROSCAN FOR PREDICTING THE GRADES OF OESOPHAGEAL VARICES IN HCV CIRRHOTIC PATIENTS
}

\begin{abstract}
Mohamed A. Hashish ${ }^{(1)}$; Mostafa Ragab ${ }^{(2)}$ and Hossam A. Mahmoud ${ }^{(3)}$ 1) Internal Medicine Department Ain Shams University Hospitals. 2) Institute of Environmental Studies and Research Ain Shams University.3) Internal Medicine Department, Faculty of Medicine, Ain Shams University.
\end{abstract}

\begin{abstract}
Introduction: oesophageal varices is one of the most common and life threatening complications of liver cirrhosis. the need for use of non invasive modalities for its prediction rather than endoscopy is important to decrease burdens and increase patient compliance .

Aim: to predict oesophageal varices presence by fibroscan and possible grading by degree of liver stiffness in Hepatitis C Virus related cirrhotic patients.

Methods: the study was carried out on 150 patients with HCV related liver cirrhosis attending Ministry of Health outpatient clinics and hospitals after being writtenly consented that they agreed to participate in this study

All patients were subjected to full history taking \& thorough clinical examination, full laboratory investigations include complete blood picture, liver profile tests , kidney function tests, abdominal ultrasound, liver stiffness measurement by fibroscan and upper GIT endoscopy.

The patients were divided according to upper GIT endoscopy results into three groups. Group 1: included 50 patients with liver cirrhosis and without oesophageal varices. Group 2: included 50 patients with liver cirrhosis and small oesophageal varices (Grade I\&II). Group 3: included 50 patients with liver cirrhosis and large esophageal varices (Grade III \& IV).

Results: there was a statistically significant increase in liver stiffness, INR , total bilirubin, ammonia level and spleen size among patients with ov than those without and among those with large varices than those with small varices, while there was a statistically significant decrease in the level of $\mathrm{Hb}$
\end{abstract}


level, platelet count and serum albumin level among patients with varices than those without and among patients with large varices than those with small varices.

Conclusion: liver stiffness measurement by Transient Elastography could be used as a valuable non-invasive screening tool for the prediction of the presence and size of oesophageal varices in HCV cirrhotic patients.

Key words: Oesophageal varices; Fibroscan; Grading; Non-invasive methods

\section{INTRODUCTION}

Cirrhosis is a consequence of almost all progressive chronic liver diseases, approximately $10 \%-20 \%$ of patients with chronic hepatitis $\mathrm{C}$ virus infection have cirrhosis at first clinical presentation, and as many as $20 \%$ $30 \%$ of those who don't have cirrhosis will eventually develop this condition and its complications within one or more decades (Ikeda et al ., 1998).

Development of oesophageal varices is a major complication that may occur in up to $90 \%$ of cirrhotic patients (Jensen 2002). Esophageal varices may lead to variceal bleeding that is a life threatening event that has an incidence of $5 \%$ in patients with small oesophageal varices and up to $15 \%$ in those with large esophageal varices. Mortality per bleeding episode is around 10\%-20\% (Carbonell et al ., 2004). Therefore, The current screening method is endoscopy at 2-3 years in patients without esophageal varices and at 1-2 years in those with small varices, this approach is invasive. That is why selection of patients with large esophageal varices at high risk for bleeding has become an issue of growing importance screening for esophageal varices in cirrhotic patients is a strong recommendation in all consensus statement (De Franchis 2005). In this respect, several clinical, biological, ultrasonographic and elastrographic (Transient Elastography-TE) methods 
have been proposed (and some of them were validated) as non-invasive alternatives to endoscopy (De Franchis et al ., 2008). This work was designed to study the validity of liver stiffness measurement by fibroscan to predict the presence of oesophageal varices in cirrhotic patients due to hepatitis $\mathrm{C}$ virus infection (Primary aim) and to determine the association between grades of esophageal varices and the degree of liver stiffness measured by fibroscan.

\section{PATIENTS AND METHODS}

This is a cross sectional study performed on 250 patients in the period from April 2015 to September 2018. Diagnosis of liver cirrhosis was based on history, clinical, laboratory and radiological data. Only 150 patients who met the inclusion criteria were recruited after being consented to participate in the study after fulfilling the following criteria:

Inclusion criteria: 1 - Adult patients $\geq 18$ years, 2-Hepatitis $\mathrm{C}$ virus infection, 3- Liver cirrhosis without moderate or massive ascites, mild pelvic ascites could be recruited, 4- no history of upper GIT bleeding or hepatocellular carcinoma and 5- BMI $<35$.

exclusion criteria for the recruited patients: 1- Patients age $<18$ years, Other causes of liver cirrhosis except HCV, 2- BMI > 35, 3- Liver cirrhosis with moderate or massive ascites, 4- History of upper GIT bleeding or hepatocellular carcinoma, 5-Patients with abdominal collaterals in abdominal ultrasound. Patients were classified into three Groups: Group 1 : included patients with liver cirrhosis and without esophageal varices. Group 2: included patients with liver cirrhosis and small esophageal varices (Grade 
I\&II). Group 3: included patients with liver cirrhosis and large esophageal varices (Grade III \& IV).

After getting a written consent from all patients, they were asked to undergo the following:

I- Full history taking with special emphasis on previous history of Schistosomiasis, history of viral hepatitis or exposure to risk factors (such as anti-Schistosomiasis injections, blood transfusion or previous surgical operations), history of jaundice, disturbed conscious level, bleeding tendency, hematemesis or melena.

II- Full clinical examination for stigmata of liver cell failure or signs of portal hypertension was obtained.

III. Laboratory investigations included

Complete blood count, serum alanine aminotransferase (ALT), serum aspartate aminotransferase (AST), total bilirubin, serum albumin, INR, Alphafeto protein and HCV Ab \& Child-Paugh score.

In the 1960's Child-Pugh Score classification system was developed by Child and Turcotte to assess the likelihood of mortality in cirrhotic patients.

The score employs five clinical measures of liver disease. Each measure is scored 1-3, with 3 indicating most severe derangement (Cholongitas et al., 2005)

\begin{tabular}{|l|c|c|c|}
\hline \multirow{2}{*}{\multicolumn{1}{c|}{ Parameter }} & \multicolumn{3}{c|}{ Score } \\
\cline { 2 - 4 } & $\mathbf{1}$ & $\mathbf{2}$ & $\mathbf{3}$ \\
\hline \hline Ascites & None & Mild & Moderate or Severe \\
\hline Encephalopathy (grade) & None & $1-2$ & $3-4$ \\
\hline Bilirubin $(\mathrm{mg} / \mathrm{dL})$ & $<2$ & $2-3$ & $>3$ \\
\hline Albumin $(\mathrm{g} / \mathrm{dL})$ & $>3.5$ & $2.8-3.5$ & $<2.8$ \\
\hline INR & $<1.7$ & $1.8-2.3$ & $>2.3$ \\
\hline
\end{tabular}


J. Environ. Sci.

Institute of Environmental Studies and Research - Ain Shams University

Interpretation of Child-Pugh score:

\begin{tabular}{|c|c|c|c|c|c|}
\hline $\begin{array}{c}\text { Child- } \\
\text { Pugh grade }\end{array}$ & $\begin{array}{c}\text { Child-Pugh } \\
\text { Score }\end{array}$ & $\begin{array}{c}\text { 1 Year } \\
\text { Survival }\end{array}$ & $\begin{array}{c}\text { 5 year } \\
\text { Survival }\end{array}$ & $\begin{array}{c}\text { 10 year } \\
\text { Survival }\end{array}$ \\
\hline \hline A & $5-6$ & $\begin{array}{c}\text { Indicates a well- } \\
\text { functioning liver }\end{array}$ & $84 \%$ & $44 \%$ & $27 \%$ \\
\hline B & $7-9$ & $\begin{array}{c}\text { Indicates significant } \\
\text { functional compromise }\end{array}$ & $62 \%$ & $20 \%$ & $10 \%$ \\
\hline C & $10-15$ & $\begin{array}{c}\text { Indicates decompensation } \\
\text { of the liver }\end{array}$ & $42 \%$ & $21 \%$ & $0 \%$ \\
\hline
\end{tabular}

IV. Abdominal ultrasonography: Using real time scanning device Toshiba, Aplio MX with convex probe, $3-5 \mathrm{uHz}$ to detect the presence of liver cirrhosis(irregular surface, coarse texture, attenuated hepatic veins),Signs of portal hypertension (presence of abdominal collaterals, splenomegaly), ascites and to exclude hepatic focal lesion.

V. upper Gastrointestinal endoscopy: Using Olympus GIF 160-Q165 (EXERA II), to evaluate the presence and degree of varices in addition to any relevant upper GIT lesions.

Classification of oesophageal varices was done according to Thakeb classification (1988):

Grade I: Small straight cords of varices confined to the lower third of esophagus.

Grade II: Moderate sized clubbed varices, with well-defined areas of normal mucosa between them, forming several distinct variceal cords and confined to the lower half of the esophagus.

Grade III: Gross varices extending into the proximal half of the esophagus, normal mucosa might not be visible in between them unless the esophagus is fully distended with air

Grade IV: Varices like those of grade 3 but with dilated capillaries on top or in between them and encroaching on esophageal lumen. 
VI. Liver Stiffness Measurement (LSM): Using Fibroscan that was performed within days following or preceding upper GI tract endoscopy, the operators were not aware of the results of endoscopy .

1. Up to ten successful acquisitions were performed on each patient. Success rate was calculated as the ratio of the number of successful acquisitions over the total number of acquisitions.

2. The median value of successful measurements was kept as representative of the liver stiffness.

3. Only LSM obtained with 10 successful acquisitions and a success rate of at least 60\% was considered reliable (Castera et al ., 2008 ).

The following shows the relation between Fibro scan reading in K Pascal and the stage of fibrosis (Vizzutti et al., 2007).

\begin{tabular}{|l|l|}
\hline F0 & $0: 2.9 \mathrm{KPa}$ \\
\hline F1 & $3: 5.9 \mathrm{KPa}$ \\
\hline F2 & $6: 8.9 \mathrm{KPa}$ \\
\hline F3 & $9: 16.9 \mathrm{KPa}$ \\
\hline F4 & $17: 75 \mathrm{KPa}$ \\
\hline
\end{tabular}

Pre-coded data was entered on the computer using "Microsoft Office Excel Software" 2010. Data was then transferred to the Statistical Package of Social Science Software program, version 21 (SPSS) to be statistically analysed. Data was summarized using mean, standard deviation for quantitative variables and frequency, percentage for qualitative ones.

Receiver operator characteristic (ROC) analysis was used to determine the optimum cut off value for the studied diagnostic markers. Univariate and multivariate regression models were constructed to determine the significant independent predictors for the occurrence of $\mathrm{OV}$, the grade of $\mathrm{OV}$ and occurrence of large OV. p values less than 0.05 was considered statistically significant. 
J. Environ. Sci.

Institute of Environmental Studies and Research - Ain Shams University

\section{RESULTS}

Table (1): comparison between patient with no varices group (1) and patients with small and large varices group (2) and (3) respectively:

\begin{tabular}{|c|c|c|c|c|c|c|}
\hline \multirow{2}{*}{\multicolumn{2}{|c|}{ Variable }} & \multirow{2}{*}{\begin{tabular}{|l|}
$\begin{array}{l}\text { Group }(1) \\
\text { no varices group }\end{array}$ \\
No. $=\mathbf{5 0}$ \\
\end{tabular}} & \multirow{3}{*}{\begin{tabular}{|l|}
$\begin{array}{l}\text { Group (2\&3) } \\
\text { Small and large ov }\end{array}$ \\
No. $=\mathbf{1 0 0}$ \\
$60.08 \pm 9.40$ \\
\end{tabular}} & \multirow{4}{*}{\begin{tabular}{|c|} 
Test value \\
1.794
\end{tabular}} & \multirow{4}{*}{\begin{tabular}{|c|} 
P-value \\
0.075
\end{tabular}} & \multirow{4}{*}{\begin{tabular}{|l} 
Sig. \\
NS
\end{tabular}} \\
\hline & & & & & & \\
\hline \multirow{2}{*}{ Age } & Mean \pm SD & $62.74 \pm 6.55$ & & & & \\
\hline & Range & $47-72$ & $29-74$ & & & \\
\hline \multirow{2}{*}{ Sex } & Females & $24(48.0 \%)$ & $50(50.0 \%)$ & \multirow{2}{*}{0.053} & \multirow{2}{*}{0.817} & \multirow{2}{*}{ NS } \\
\hline & \begin{tabular}{|l|} 
Males \\
\end{tabular} & $26(52.0 \%)$ & $50(50.0 \%)$ & & & \\
\hline \multirow{2}{*}{ Creatinine } & Mean \pm SD & $1.08 \pm 0.27$ & $1.03 \pm 0.27$ & \multirow{2}{*}{1.019} & \multirow{2}{*}{0.310} & \multirow{2}{*}{ NS } \\
\hline & Range & $0.5-1.44$ & $0.5-1.44$ & & & \\
\hline \multirow{3}{*}{$\begin{array}{l}\text { Child } \\
\text { score }\end{array}$} & Child A & $50(100.0 \%)$ & $41(41.0 \%)$ & \multirow{3}{*}{48.626} & \multirow{3}{*}{0.000} & \multirow{3}{*}{ HS } \\
\hline & $\begin{array}{l}\text { Child B } \\
\text {. }\end{array}$ & $0(0.0 \%)$ & $41(41.0 \%)$ & & & \\
\hline & Child C & $0(0.0 \%)$ & $18(18.0 \%)$ & & & \\
\hline AST & $\begin{array}{l}\text { Mean } \pm \text { SD } \\
\text { Range }\end{array}$ & $\begin{array}{c}51.76 \pm 16.06 \\
32-92\end{array}$ & $\begin{array}{c}58.01 \pm 22.06 \\
22-112\end{array}$ & $-1.780 \bullet$ & 0.077 & NS \\
\hline ALT & $\begin{array}{l}\text { Mean } \pm \text { SD } \\
\text { Range }\end{array}$ & $\begin{array}{c}41.56 \pm 18.50 \\
19-88\end{array}$ & $\begin{array}{c}38.06 \pm 17.68 \\
13-90\end{array}$ & $1.125 \bullet$ & 0.262 & NS \\
\hline INR & \begin{tabular}{|l|}
$\begin{array}{l}\text { Mean } \pm \text { SD } \\
\text { Range }\end{array}$ \\
\end{tabular} & $\begin{array}{c}1.26 \pm 0.20 \\
1-1.9 \\
\end{array}$ & $\begin{array}{c}2.04 \pm 0.54 \\
1.1-3.5\end{array}$ & $-9.780 \bullet$ & 0.000 & HS \\
\hline $\begin{array}{l}\text { Total } \\
\text { Bilirubin }\end{array}$ & $\begin{array}{l}\text { Mean } \pm \text { SD } \\
\text { Range }\end{array}$ & $\begin{array}{c}1.20 \pm 0.14 \\
0.9-1.5\end{array}$ & $\begin{array}{c}2.02 \pm 0.56 \\
1.1-3.7\end{array}$ & $-10.212 \bullet$ & 0.000 & HS \\
\hline Albumin & $\begin{array}{l}\text { Mean } \pm \text { SD } \\
\text { Range }\end{array}$ & $\begin{array}{c}3.76 \pm 0.35 \\
3.1-4.8\end{array}$ & $\begin{array}{c}3.24 \pm 0.59 \\
1.8-4.8\end{array}$ & $5.745 \bullet$ & 0.000 & HS \\
\hline Hemoglobin & $\begin{array}{l}\text { Mean } \pm \text { SD } \\
\text { Range }\end{array}$ & $\begin{array}{c}11.66 \pm 0.87 \\
9.3-13.2\end{array}$ & $\begin{array}{c}10.35 \pm 1.27 \\
7.8-13.2\end{array}$ & $6.565 \bullet$ & 0.000 & HS \\
\hline TLC & \begin{tabular}{|l|} 
Mean \pm SD \\
Range
\end{tabular} & $\begin{array}{c}4.47 \pm 1.07 \\
2-6.5\end{array}$ & $\begin{array}{c}4.41 \pm 1.15 \\
1.8-6.5\end{array}$ & $0.315 \bullet$ & 0.753 & NS \\
\hline Platelet count & \begin{tabular}{|l|}
$\begin{array}{l}\text { Mean } \pm \text { SD } \\
\text { Range }\end{array}$ \\
\end{tabular} & $\begin{array}{c}137.84 \pm 21.67 \\
99-170 \\
\end{array}$ & $\begin{array}{c}96.83 \pm 28.24 \\
41-187 \\
\end{array}$ & $9.020 \bullet$ & 0.000 & HS \\
\hline Ammonia & $\begin{array}{l}\text { Mean } \pm \text { SD } \\
\text { Range }\end{array}$ & $\begin{array}{c}40.96 \pm 15.97 \\
15-87\end{array}$ & $\begin{array}{c}91.02 \pm 30.08 \\
23-160\end{array}$ & $-11.005 \bullet$ & 0.000 & HS \\
\hline AFP & $\begin{array}{l}\text { Median(IQR) } \\
\text { Range }\end{array}$ & $\begin{array}{c}4.10(2.4-6) \\
1-10\end{array}$ & $\begin{array}{c}4.00(2.35-6.1) \\
1-10\end{array}$ & $-0.024 \dagger$ & 0.981 & NS \\
\hline Spleen size & $\begin{array}{l}\text { Mean } \pm \text { SD } \\
\text { Range }\end{array}$ & $\begin{array}{c}12.12 \pm 1.68 \\
8.7-15\end{array}$ & $\begin{array}{c}15.17 \pm 1.65 \\
12-20.1\end{array}$ & $-10.609 \bullet$ & 0.000 & HS \\
\hline Liver stiffness & $\begin{array}{l}\text { Mean } \pm \text { SD } \\
\text { Range }\end{array}$ & $\begin{array}{l}26.62 \pm 6.05 \\
17-39\end{array}$ & $\begin{array}{l}52.82 \pm 13.80 \\
33-75\end{array}$ & -12.801 & 0.000 & HS \\
\hline
\end{tabular}

NS: Non significant; S: Significant; HS: Highly significant

•: Independent t-test; ‡: Mann Whitney test

AST: Aspartate aminotransferase, ALT: Alanine aminotransferase, INR: International Normalised Ratio, TLC: total leucocytic count , AFP: Alphafetoprotein . 
The previous table showed that there was no statistically significant difference between the different studied group as regard age , sex , creatinine level, AST,ALT,TLC and AFP . Child Pugh grade was statistically highly significant among patients with ov than patients without ov with p-value < 0.001. there was a high statistically significant increase in the level of INR, Total bilirubin , serum ammonia level, splenic size and fibro scan results among patients with small and large varices group (2) and (3) respectively than the patients with no varices in group (1)., while there was a high statistically decrease in the level of serum albumin, haemoglobin , and platelet count among patients of group (2) and (3) than among patients in group (1).

Table (2): Logistic regression analysis for predictors of presence of oesophageal varices

\begin{tabular}{|c|c|c|c|c|}
\hline \multirow{2}{*}{ Predictors } & \multirow{2}{*}{ P-value } & \multirow{2}{*}{ Odds ratio (OR) } & \multicolumn{2}{|c|}{ 95\% C.I.for OR } \\
\cline { 3 - 5 } & & Lower & Upper \\
\hline \hline INR & 0.000 & 12.093 & 11.163 & 14.341 \\
\hline Total bilirubin & 0.000 & 7.721 & 1.537 & 57.198 \\
\hline Albumin & 0.000 & 0.101 & 0.038 & 0.268 \\
\hline Hemoglobin & 0.000 & 0.367 & 0.252 & 0.535 \\
\hline Platelet count & 0.000 & 0.948 & 0.931 & 0.964 \\
\hline Ammonia & 0.000 & 1.082 & 1.056 & 1.108 \\
\hline Fibro scan & 0.000 & 2.052 & 1.411 & 2.984 \\
\hline Spleen size & 0.000 & 4.140 & 2.532 & 6.770 \\
\hline
\end{tabular}

INR: International Normalised Ratio

The previous table shows that all the previous studied parameters were found in a highly statistically significant association with presence of oesophageal varices. 
Table (3): Receiver operating characteristic curve (ROC) for the diagnostic accuracy of oesophageal varices predictors

\begin{tabular}{|c|c|c|c|c|c|c||}
\hline predictors & Cut off point & AUC & Sensitivity & Specificity & + PV & -PV \\
\hline \hline INR & $>1.51$ & 0.932 & 84.000 & 96.000 & 97.700 & 75.000 \\
\hline Total bilirubin & $>1.32$ & 0.960 & 93.000 & 88.000 & 93.900 & 86.300 \\
\hline Albumin & $\leq 3.2$ & 0.773 & 49.000 & 96.000 & 96.100 & 48.500 \\
\hline Hemoglobin & $\leq 10.4$ & 0.797 & 57.000 & 94.000 & 95.000 & 52.200 \\
\hline Platelet count & $\leq 111$ & 0.878 & 80.000 & 82.000 & 89.900 & 67.200 \\
\hline Ammonia & $>60$ & 0.918 & 86.000 & 90.000 & 94.500 & 76.300 \\
\hline $\begin{array}{c}\text { Liver stiffness } \\
\text { measurment }\end{array}$ & $>35$ & 0.986 & 90.910 & 96.000 & 97.800 & 84.200 \\
\hline Spleen size & $>13.7$ & 0.913 & 81.000 & 86.000 & 92.000 & 69.400 \\
\hline
\end{tabular}

INR: international normalised ratio

The previous ROC curve shows the best cut off point for each independent predictor of the presence of oesophageal varices with its sensitivity, specificity, positive predictive value, negative predictive value and area under curve (AUC). The table shows that the fibroscan level was found the best predictor for presence of oesophageal varices with the higher AUC of $98.6 \%$. 
Table (4): Relation of oesophageal varices size with laboratory data of the studied patients

\begin{tabular}{|c|c|c|c|c|c|c|c|c|c|c|}
\hline & \multicolumn{3}{|c|}{ Oesophageal varices Groups } & \multirow{3}{*}{$\begin{array}{c}\text { Test } \\
\text { value }\end{array}$} & \multirow{3}{*}{$\begin{array}{c}\text { P- } \\
\text { value }\end{array}$} & \multirow{3}{*}{ Sig. } & \multicolumn{3}{|c|}{\begin{tabular}{|c} 
Post Hoc Analysis by \\
LSD
\end{tabular}} \\
\hline & & \multirow{2}{*}{$\begin{array}{c}\begin{array}{c}\text { No varices } \\
\text { Group (1) }\end{array} \\
\text { No. }=\mathbf{5 0}\end{array}$} & \multirow{2}{*}{\begin{tabular}{|c|}
$\begin{array}{c}\text { Small varices } \\
\text { Group (2) }\end{array}$ \\
No. $=\mathbf{5 0}$ \\
\end{tabular}} & \multirow{2}{*}{\begin{tabular}{|c|}
$\begin{array}{c}\text { Large } \\
\text { varices } \\
\text { Group (3) }\end{array}$ \\
No. $=\mathbf{5 0}$ \\
\end{tabular}} & & & & \multirow{2}{*}{ P1 } & \multirow{2}{*}{ P2 } & \multirow{2}{*}{ P3 } \\
\hline & & & & & & & & & & \\
\hline \multirow{2}{*}{ AST } & Mean \pm SD & $51.76 \pm 16.06$ & $55.80 \pm 21.34$ & $60.22 \pm 22.74$ & \multirow{2}{*}{2.182} & \multirow{2}{*}{0.116} & \multirow{2}{*}{ NS } & \multirow{2}{*}{0.320} & \multirow{2}{*}{0.038} & \multirow{2}{*}{0.277} \\
\hline & Range & $32-92$ & $22-107$ & $24-112$ & & & & & & \\
\hline \multirow{2}{*}{ ALT } & Mean \pm SD & $41.56 \pm 18.50$ & $42.06 \pm 18.93$ & $34.06 \pm 15.52$ & \multirow{2}{*}{$3.200 \bullet$} & \multirow{2}{*}{0.044} & \multirow{2}{*}{$\mathrm{S}$} & \multirow{2}{*}{0.888} & \multirow{2}{*}{0.036} & \multirow{2}{*}{0.025} \\
\hline & Range & $19-88$ & $15-90$ & $13-87$ & & & & & & \\
\hline \multirow{2}{*}{ INR } & Mean \pm SD & $1.26 \pm 0.20$ & $1.84 \pm 0.42$ & $2.24 \pm 0.58$ & \multirow{2}{*}{$64.863 \bullet$} & \multirow{2}{*}{0.000} & \multirow{2}{*}{ HS } & \multirow{2}{*}{0.000} & \multirow{2}{*}{0.000} & 000 \\
\hline & Range & $1-1.9$ & $1.1-2.9$ & $1.1-3.5$ & & & & & & .000 \\
\hline Total & Mean \pm SD & $1.20 \pm 0.14$ & $1.88 \pm 0.45$ & $2.15 \pm 0.62$ & $59324 \bullet$ & (1000 & HS & 0000 & 0 & 0003 \\
\hline bilirubin & Range & $0.9-1.5$ & $1.1-3$ & $1.2-3.7$ & $59.324^{\circ}$ & 0.000 & HS & 0.000 & 0.000 & 0.003 \\
\hline Alt $>$ & Mean \pm SD & $3.76 \pm 0.35$ & $3.38 \pm 0.52$ & $3.09 \pm 0.62$ & & 0000 & IS & lo & 0000 & 006 \\
\hline Albumin & Range & $3.1-4.8$ & $2.3-4.8$ & $1.8-4.1$ & $3^{\bullet}$ & 0.000 & HS & 0.000 & 0.000 & .000 \\
\hline Hemog & Mean \pm SD & $11.66 \pm 0.87$ & $11.02 \pm 1.11$ & $9.68 \pm 1.04$ & & 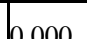 & HS & 0 & 0 & \\
\hline Hemoglobin & Range & $9.3-13.2$ & $8.6-13.2$ & $7.8-13$ & 499. & 0.000 & HS & 0.002 & 0.000 & 0.000 \\
\hline TI $C$ & Mean \pm SD & $4.47 \pm 1.07$ & $4.47 \pm 1.07$ & $4.35 \pm 1.23$ & & & & 000 & & \\
\hline $1 \mathrm{LC}$ & Range & $2-6.5$ & $2-6.5$ & $1.8-6.5$ & & & INS & 000 & 81 & 581 \\
\hline Platelet & Mean \pm SD & $\begin{array}{c}137.84 \pm \\
21.67\end{array}$ & $\begin{array}{l}109.82 \pm \\
28.12\end{array}$ & $83.84 \pm 21.83$ & $62.986^{\bullet}$ & 0.000 & HS & 0.000 & 0.000 & 0.000 \\
\hline & Range & $99-170$ & $65-187$ & $41-143$ & & & & & & \\
\hline & Mean \pm SD & $40.96 \pm 15.97$ & $777.16 \pm 29.40$ & $\begin{array}{c}104.88 \pm \\
23.91\end{array}$ & $26 \bullet$ & 0.000 & HS & 0.000 & 0.000 & .000 \\
\hline & Range & $15-87$ & $23-132$ & $76-160$ & & & & & & \\
\hline AFP & Median(IQR & $4.10(2.4-6)$ & $4.10(2.4-6)$ & $4.00(2.3-6.2)$ & $0.237 t$ & 0.888 & NS & 0.806 & 0.839 & 0.615 \\
\hline & Range & $1-10$ & $1-10$ & $1-9$ & & & & & & \\
\hline Spleen size & $\begin{array}{l}\text { Mean } \pm \text { SD } \\
\text { Range }\end{array}$ & \begin{tabular}{|c|}
$12.12 \pm 1.68$ \\
$8.7-15$
\end{tabular} & $\begin{array}{c}14.78 \pm 1.52 \\
12-20.1\end{array}$ & $\begin{array}{c}15.56 \pm 1.70 \\
12.5-20.1 \\
\end{array}$ & $60.824 \bullet$ & 0.000 & HS & 0.000 & 0.000 & 0.019 \\
\hline $\begin{array}{c}\text { Liver } \\
\text { stiffness } \\
\text { measurment }\end{array}$ & $\begin{array}{l}\text { Mean } \pm \text { SD } \\
\text { Range }\end{array}$ & $\begin{array}{c}26.62 \pm 6.05 \\
17-39\end{array}$ & $\begin{array}{c}41.67 \pm 5.91 \\
33-50\end{array}$ & $\begin{array}{c}64.20 \pm 9.56 \\
44-75\end{array}$ & 327.040 & 0.000 & HS & 0.000 & 0.000 & 0.000 \\
\hline
\end{tabular}

NS: Non significant; S: Significant; HS: Highly significant

$\because$ One Way ANOVA test; $;:$ Kruskal Wallis test.

AST: Aspartate aminotransferase, ALT: Alanine aminotransferase, INR: International Normalised Ratio, TLC: total leucocytic count, AFP: Alpha-fetoprotein .

The previous table shows that there was highly statistically significant decrease in the level of ALT, albumin, hemoglobin and platelet count with the increase of oesophageal varices size and also highly statistically significant increase in the level of INR, total bilirubin, ammonia level, spleen 
J. Environ. Sci.

Institute of Environmental Studies and Research - Ain Shams University

size and fibroscan levels with the increase of oesophageal varices size while no statistically significant relation found with AST, TLC and AFP.

Table (5): Logistic regression analysis for predictors of size of oesophageal varices:

\begin{tabular}{|l|l|l|l|l|}
\hline \multirow{2}{*}{ Predictors } & \multirow{2}{*}{ P-value } & \multirow{2}{*}{ Odds ratio (OR) } & \multicolumn{2}{c|}{ 95\% C.I.for OR } \\
\cline { 4 - 5 } & & & Lower & \multicolumn{1}{c|}{ Upper } \\
\hline \hline ALT & 0.028 & 0.973 & 0.949 & 0.997 \\
\hline INR & 0.001 & 4.770 & 1.943 & 11.711 \\
\hline Total bilirubin & 0.019 & 2.545 & 1.167 & 5.551 \\
\hline Albumin & 0.019 & 0.416 & 0.199 & 0.868 \\
\hline Hemoglobin & 0.000 & 0.314 & 0.191 & 0.516 \\
\hline Platelet count & 0.000 & 0.956 & 0.935 & 0.977 \\
\hline Ammonia & 0.000 & 1.041 & 1.021 & 1.061 \\
\hline $\begin{array}{l}\text { Liver stiffness } \\
\text { measurement }\end{array}$ & 0.002 & 1.695 & 1.205 & 2.384 \\
\hline Spleen size & 0.023 & 1.360 & 1.044 & 1.772 \\
\hline
\end{tabular}

ALT: alanine aminotransferase, INR: international normalized ratio.

The previous table shows that there was highly statistically significant association found between all the studied parameters and the size of oesophageal varices of the studied patients.

Table (6): ROC curve analysis for predictors of size of oesophageal varicies

\begin{tabular}{|l|l|l|l|l|l|l|}
\hline Predictors & Cut off point & AUC & Sensitivity & Specificity & +PV & -PV \\
\hline \hline ALT & $\leq 50$ & 0.623 & 92.00 & 30.00 & 56.8 & 78.9 \\
\hline INR & $>2.2$ & 0.698 & 44.00 & 86.00 & 75.9 & 60.6 \\
\hline Total bilirubin & $>2.45$ & 0.618 & 32.00 & 90.00 & 76.2 & 57.0 \\
\hline Albumin & $\leq 3$ & 0.613 & 48.00 & 72.00 & 63.2 & 58.1 \\
\hline Hemoglobin & $\leq 10.2$ & 0.804 & 78.00 & 72.00 & 73.6 & 76.6 \\
\hline Platelet count & $\leq 88$ & 0.755 & 52.00 & 84.00 & 76.5 & 63.6 \\
\hline Ammonia & $>75$ & 0.744 & 100.00 & 46.00 & 64.9 & 100.0 \\
\hline Fibro scan & $>50$ & 0.981 & 89.80 & 100.00 & 100.0 & 90.9 \\
\hline Spleen size & $>14.7$ & 0.645 & 70.00 & 58.00 & 62.5 & 65.9 \\
\hline
\end{tabular}

ALT: alanine aminotransferase, INR: international normalized ratio. 
The previous ROC curve showed the best cut off point for each independent predictors of the size of oesophageal varicies of the studied patients with its sensitivity, specificity, positive predictive value, negative predictive value and area under curve (AUC). The table showed that the fibroscan level was found the best predictor to differentiate between small and large oesophageal varicies with the higher AUC of $98.1 \%$

\section{DISCUSSION}

Bleeding from oesophago-gastric varices is the most important complication of cirrhosis (D'Amico et al ., 2006).The first crucial step in prevention is to identify the patients at risk for bleeding by endoscopic screening, in order to select them for prophylactic treatment (Garcia-Tsao et $a l$., 2007 ). Since a variable proportion of patients will not have varices; thus, screening all cirrhotic patients with upper GI endoscopy implies a number of unnecessary endoscopies, which increase the workload of endoscopy units. In addition, compliance with endoscopic screening recommendations may be limited (Berzigotti et al., 2008 ) .Predicting the presence of esophageal varices by non -invasive means would permit to restrict the performance of endoscopy to those patients with a high probability of having varices (Bureau et al., 2008). The aim of this study was to predict the presence of esophageal varices by measurement of liver stiffness by fibroscan in cirrhotic patients due to hepatitis $\mathrm{C}$ virus infection and to determine the grade of esophageal varices by the degree of liver stiffness.

In the present study Child Pugh score was statistically significant higher in patients with esophageal varices (Groups 2-3) than those without 
esophageal varices (Group 1) and this is in agreement with Madhotra et al., (2002) who found a significant relation between presence of varices and increased Child score. Thus, the more advanced liver disease the more likely the presence of varices.

In the present study, platelet count was significantly lower in patients with esophageal varices-Group $2 \& 3$ ( mean $=96.83 \pm 28.24)$, than in patients without oesophageal varices -group 1 (mean $=137.84 \pm 21.67), p$ value $=0.000$. Platelet count may decrease for several reasons in patients with chronic liver disease. Madthora et al., (2002) reported that $32 \%$ of the studied cirrhotic patients had platelet count less than $68000 / \mathrm{mm} 3$ without detectable splenomegaly; this might be explained by the insufficient synthesis of thrombopoietin. Other potential explanations for this phenomenon are presence of antithrombocytic antibodies and thrombocyte associated immunoglobulin, which can be found in the sera of patients with liver diseases (Winkfeld et al., 2003 ). Thus the use of platelet count alone as a non-invasive predictor of esophageal varices can be misleading and cannot be solely attributed to portal hypertension. Indeed, the use of the platelet count/spleen diameter ratio bypasses this possible drawback since it “normalizes" platelet count to splenic sequestration (Giannini et al ., 2003).

As regard spleen size, we found that it was statistically significantly higher in patients with esophageal varices-Group $2 \& 3$ (mean $=15.17 \pm 1.65$ ) than those without oesophageal varices -group 1 (mean $=12.12 \pm 1.68)$, $\mathrm{p}$ value $=0.000$, so measurement of splenic size by ultrasonography is 
considered a non-invasive predictor indicator of the development of gastroesophageal varices in liver cirrhosis (Khadka et al., 2017).

In this study liver stiffness measurement was significantly higher in patients with esophageal varices (Groups $2 \& 3$ ) mean $=52.82 \pm 13.80 \mathrm{KPa}$ than those with no varices (Group 1) ) mean $=26.62 \pm 6.05 \mathrm{KPa}, \mathrm{p}$-value $<0.001$; at the best cut off value $>35 \mathrm{KPa}$,AUC of $98.6 \%$, sensitivity was $90.9 \%$, specificity was $96 \%$, also it was significantly higher in patients with large varices (group 3) mean $=64.20 \pm 9.56 \mathrm{KPa}$ than in patients with small varices $($ Group 2$)$ mean $=41.67 \pm 5.91 \mathrm{KPa}$; at the best cut off value $>50 \mathrm{KPa}$ , AUC of $98.1 \%$, sensitivity of $89.8 \%$ and specificity of $100 \%$.

In agreement with our results Sporea et al., (2011), they studied 1000 patients with transient elastography for liver stiffness measurement and showed more or less equivalent cut off values (For the presence of varices, the optimal Fibroscan cut-off was $31 \mathrm{kPa}$ and for bleeding cut-off was 50.7 $\mathrm{KPa}$ ), according to Lebrec et al., (1980) ; the larger the size of varices the higher risk of bleeding and according to Sporea et al., (2011), study cut off value for transient elastography to predict risk of bleeding could be considered as cut off value for prediction of large varices. Moreover, studies carried out by Vizzutti et al., (2007), a cut- off value for prediction of varices was $17.6 \mathrm{kPa}$, these cut off values are smaller than the values reported in this study, but the different demographics and patients characteristics as well as the type of fibroscan machines could be the reason for these discrepancy. More over Castera et al., (2009) showed that Transient elastography could be a valuable tool in diagnosis of cirrhosis but cannot replace endoscopy for variceal screening On multivariate analysis of other non-invasive parameters 
for the detection of presence of varices in current results, the fibroscan has the highest significant value which confirm the previous study carried by Kazemi et al., (2006). Accordingly, liver stiffness measurement by fibroscan is suggested as a simple non-invasive physical parameter, allows Identifying patients with well-compensated cirrhosis a large Group ineligible for variceal screening as having a low probability of bearing varices and particularly large varices, limiting therefore the indications of endoscopic screening. The use of fibroscan in the prediction as well as grading of esophageal varices could be very helpful on planning for the management of cirrhotic patients to prevent the morbidity and mortality developing from bleeding varices.

\section{CONCLUSION}

Liver stiffness measurement by fibroscan is valuable in predicting the presence of esophageal varices in patients with liver cirrhosis and of higher diagnostic value than other non- invasive parameters in predicting the size of esophageal varices. It may help to select patients for endoscopic screening.

\section{REFERENCES}

Berzigotti A, Gilabert R, Abraldes JG, Nicolau C, Bru C, Bosch J, GarcíaPagan JC. (2008): Noninvasive prediction of clinically significant portal hypertension and esophageal varices in patients with compensated liver cirrhosis, Am J Gastroenterol, 103(5), pp. 1159-6.

Bhattarai S, Dewan KR, Shrestha G, Patowary BS (2017): Non-Invasive Predictors of Gastro-Oesophageal Varices, JNMA J Nepal Med Assoc, 56(207), pp. 298-303. 
Bureau C, Metivier S, Peron JM, Selves J, Robic MA, Gourraud PA, Rouquet O, Dupuis E, Alric L, Vinel JP. (2008): Transient elastography accurately predicts presence of significant portal hypertension in patients with chronic liver disease, Aliment Pharmacol Ther., 27(12), pp. 1261-8.

Carbonell N, Pauwels A, Serfaty L, Fourdan O, Lévy VG, Poupon R. (2004): Improved survival after variceal bleeding in patients with cirrhosis over the past two decades, Hepatology., 40(3), pp. 6529.

Castera L, Forns X, Alberti A. (2008): Non-invasive evaluation of liver fibrosis using transient elastography, J Hepatol, 48(5), pp. 835-47.

Castéra L, Le Bail B, Roudot-Thoraval F, Bernard PH, Foucher J, Merrouche W, Couzigou P, de Lédinghen V. (2009):Early detection in routine clinical practice of cirrhosis and oesophageal varices in chronic hepatitis $\mathrm{C}$ : comparison of transient elastography (FibroScan) with standard laboratory tests and noninvasive scores, J Hepatol, 50(1), pp. 59-68.

Cholongitas, E; Papatheodoridis, GV; Vangeli, M; Terreni, N; Patch, D; Burroughs, AK (Dec 2005): Systematic review: The model for end-stage liver disease--should it replace Child-Pugh's classification for assessing prognosis in cirrhosis?, Alimentary Pharmacology \& Therapeutics, 22(11-12), pp. 1079-89.

D'Amico G, Garcia-Pagan JC, Luca A, Bosch J (2006): Hepatic vein pressure gradient reduction and prevention of variceal bleeding in cirrhosis: a systematic review, Gastroenterology, 131(5), pp. 1611-24.

De Franchis R (2005): Evolving consensus in portal hypertension. Report of the Baveno IV consensus workshop on methodology of diagnosis and therapy in portal hypertension., J Hepatol., 43(1), pp. 167-76..

De Franchis R, Eisen GM, Laine L, Fernandez-Urien I, Herrerias JM, Brown RD, Fisher L, Vargas HE, Vargo J, Thompson J, Eliakim R. (2008): Esophageal capsule endoscopy for screening and surveillance of esophageal varices in patients with portal hypertension., Hepatology., 47(5), pp. 1595-603. 
Garcia-Tsao G, Sanyal AJ, Grace ND, and Carey WD (2007): Practice Guidelines Committee of American Association for Study of Liver Diseases; Practice Parameters Committee of American College of Gastroenterology. Prevention and management of gastroesophagealvarices and variceal hemorrhage in cirrhosis, Am J Gastroenterol, 102(9), pp. 2086-102.

Giannini E, Botta F, Borro P, Risso D, Romagnoli P, Fasoli A, Mele MR, Testa E, Mansi C, Savarino V, Testa R. (2003): Platelet count/spleen diameter ratio: proposal and validation of a noninvasive parameter to predict the presence of oesophageal varices in patients with liver cirrhosis, Eur J Gastroenterol Hepatol, 52(8), pp. 1200-5.

Ikeda K, Saitoh S, Suzuki Y, Kobayashi M, Tsubota A, Koida I, Arase Y, Fukuda M, Chayama K, Murashima N, Kumada H. (1998): Disease progression and hepatocellular carcinogenesis in patients with chronic viral hepatitis: a prospective observation of 2215 patients, J Hepatol, 28(6), pp. 930-8.

Jensen DM. (2002 ): Endoscopic screening for varices in cirrhosis: findings, implications, and outcomes., Gastroenterology., 122(6), pp. 162030 .

Kazemi F, Kettaneh A, N'kontchou G, Pinto E, Ganne-Carrie N, Trinchet JC, Beaugrand M (2006): Liver stiffness measurement selects patients with cirrhosis at risk of bearing large oesophageal varices, J Hepatol, 45(2), pp. 230-5.

Khadka D, Prajapati S, Kc S, Shrestha JK, Karki N, Jaishi B, Regmi K, Khadka S. (2017): Significance of Non-Invasive Markers as Predictor of Esophageal Varices in Liver Cirrhosis., JNMA J Nepal Med Assoc., 56(208), pp. 412-416.

Lebrec D, De Fleury P, Rueff B, Nahum H, Benhamou JP (1980): Portal hypertension, size of esophageal varices, and risk of gastrointestinal bleeding in alcoholic cirrhosis., Gastroenterology, 79(6), pp. 1139-44. 
Madhotra R, Mulcahy HE, Willner I, Reuben A. (2002): Prediction of esophageal varices in patients with cirrhosis, J Clin Gastroenterol, 34(1), pp. 81-5.

Sporea I, Raţiu I, Sirli R, Popescu A, Bota S. (2011): Value of transient elastography for the prediction of variceal bleeding, World $\mathrm{J}$ Gastroenterol, 17(17), pp. 2206-10.

Vizzutti F, Arena U, Rega L, Romanelli RG, Colagrande S, Cuofano S, Moscarella S, Belli G, Marra F, Laffi G, Pinzani M. (2007): Performance of Doppler ultrasound in the prediction of severe portal hypertension in hepatitis $\mathrm{C}$ virus-related chronic liver disease, Liver Int, 27(10), pp. 1379-88

Vizzutti F, Arena U, Romanelli RG, Rega L, Foschi M, Colagrande S, Petrarca A, Moscarella S, Belli G, Zignego AL, Marra F, Laffi G, Pinzani M. (2007): Liver stiffness measurement predicts severe portal hypertension in patients with HCV-related cirrhosis, Hepatology, 45(5), pp. 1290-7.

Winkfield B, Aubé C, Burtin P, Calès P. (2003): Inter-observer and intraobserver variability in hepatology, Eur J Gastroenterol Hepatol, 15(9), pp. 959-66.

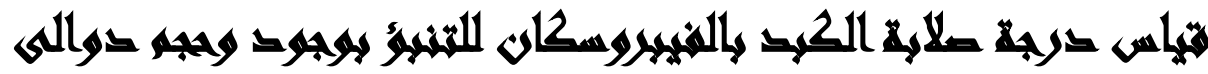

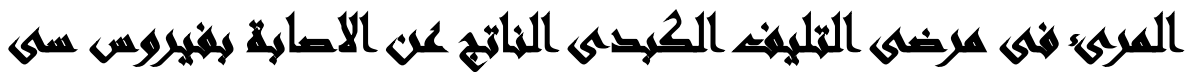

$[r]$

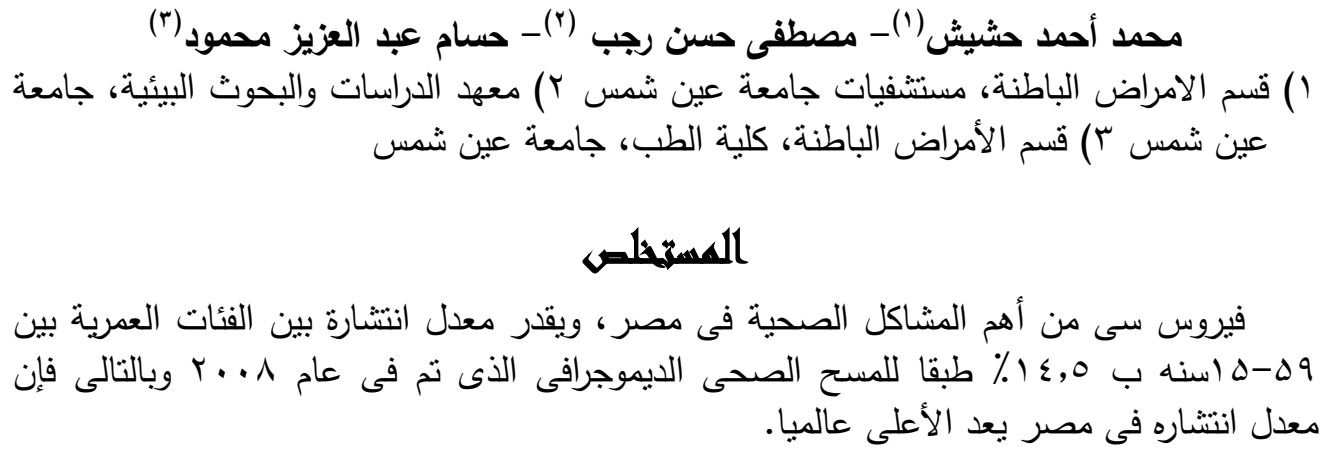


J. Environ. Sci.

Institute of Environmental Studies and Research - Ain Shams University

تليف الكبد هو المرحلة الاخيرة من تطور أى من أمراض الكبد المزمنة ويجعل المريض عرضه

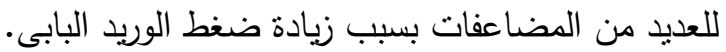

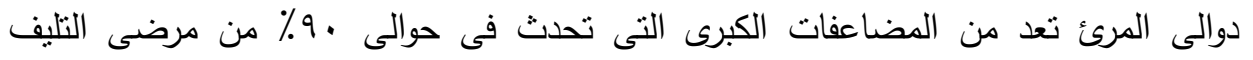

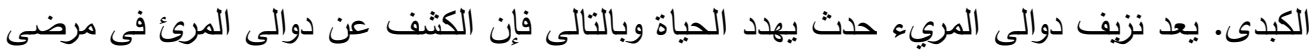

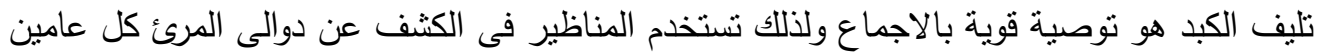

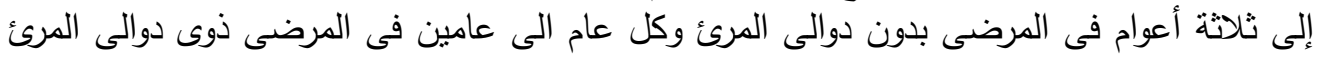

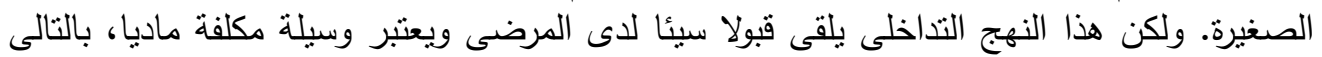

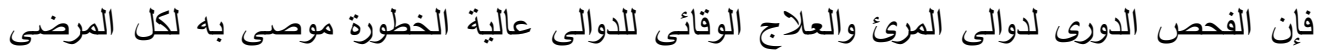

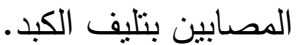
وبالرغم من أن المناظير تعد هي المعيار الذهبى لتتخيص دوالى المئى المرئ إلا أن هذه الخدمة غير متوفرة بنطاق واسع فى مراكز الرعاية الصحية.

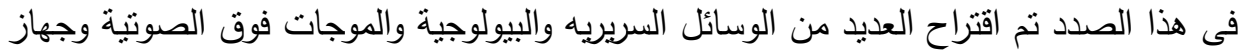

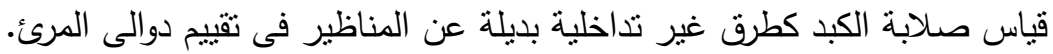

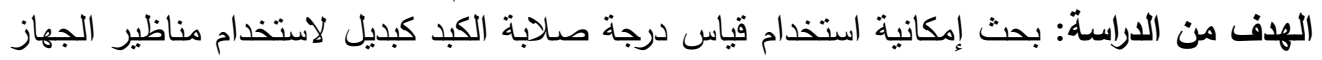

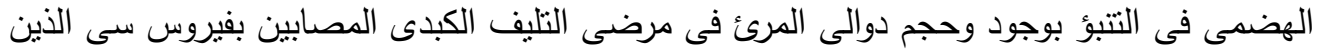
لم يسبق لهم النزف من دوالى المرئ من قبو فيل.

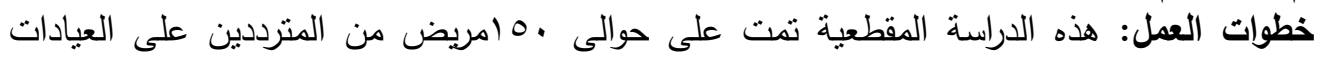

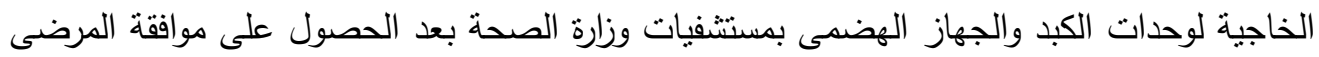
ل المشاركة في هذه الدراسة.

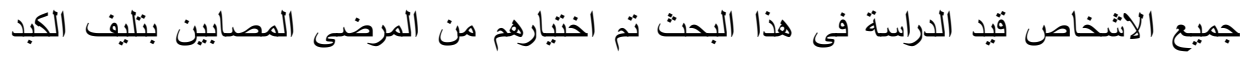

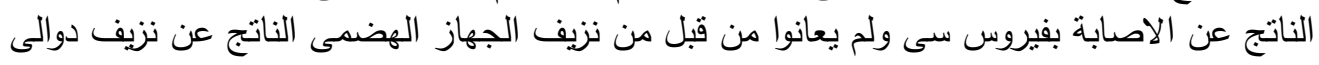

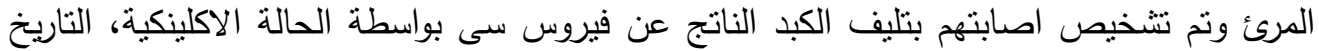

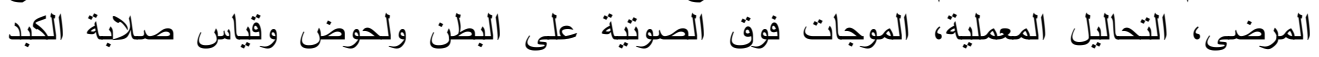
بواسطة جهاز الفيبروسكان.

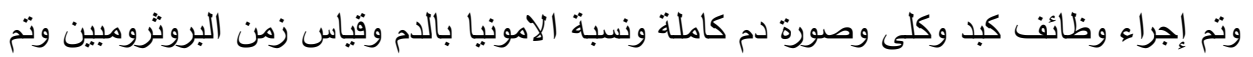

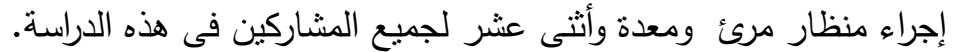

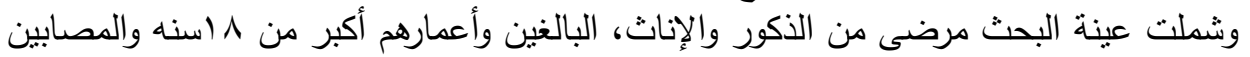

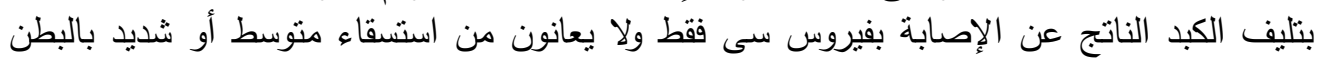

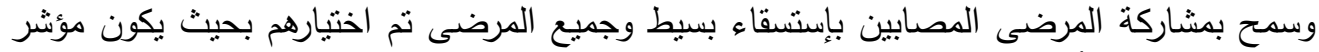

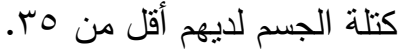

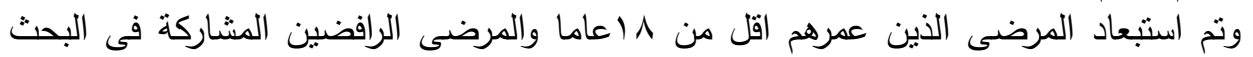

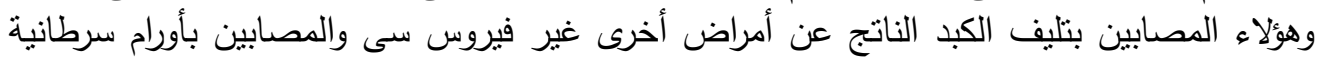
بالكبد والذين سبق إصابتهم بنزيف من دوالى المرئ. 
نتيجة البحث: وجد أنه هناك زيادة ملحوظة فى درجة صلابة الكبد ونسبة الصفراء ونسبة الامونيا

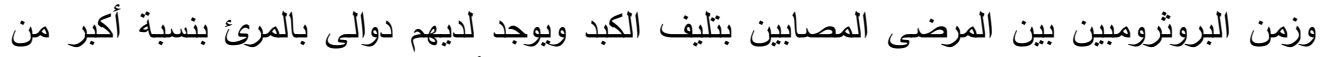

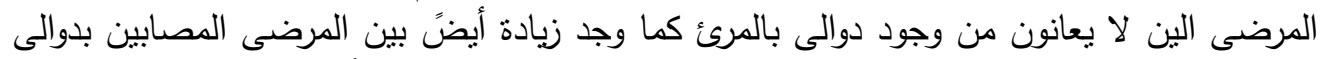

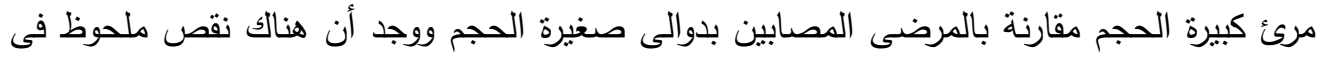

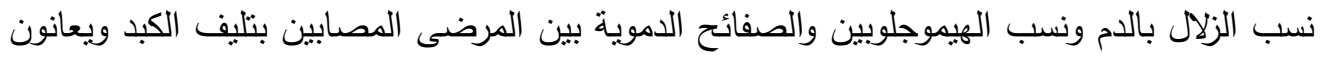

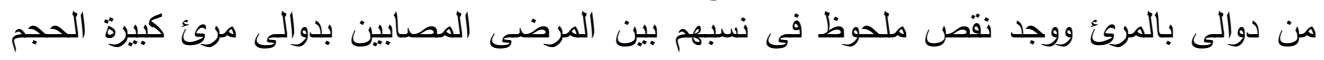

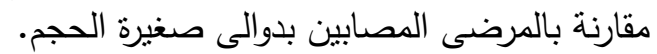
الاستتتاج: قياس درجة صلابة الكابة الكبد بواسطة جهاز الفيبروسكان وجد أنه وسيلة جيدة كبديل لاستخدام

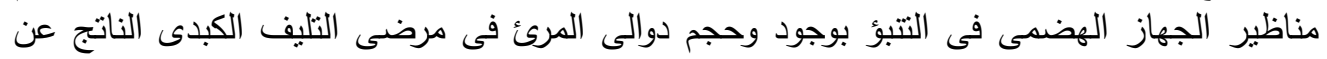
الإصابة بفيروس سى. 